\title{
A holistic framework for the perceived return on investment in an MBA
}

\author{
T. Carmichael* \\ Graduate School of Business Administration, University of the Witwatersrand, \\ PO Box 98, Wits 2050, Republic of South Africa \\ carmichael.t@wbs.wits.ac.za \\ M. Sutherland \\ Graduate School of Business Administration, University of the Witwatersrand, \\ PO Box 98, Wits 2050, Republic of South Africa

\section{Received March 2005}

\begin{abstract}
Traditional models for calculating the Return on Investment (ROI) of education examine the costs and benefits of such interventions in financial terms. The aim of this study was to explore other important variables over and above those of a financial nature, which should be considered by MBA students when holistically evaluating the ROI of undertaking this qualification.
\end{abstract}

The study was exploratory and perception based; a pilot contribution to the debate on the value of an MBA and a baseline for further research. In the two-phased study, 54 graduates from Wits Business School articulated a number of input (cost), output (benefits) and process variables that they perceived as important when holistically evaluating the ROI of their studies. An overwhelming majority perceived that the benefits of doing an MBA outweigh the costs, taking all variables into account.

Although the findings cannot be generalised to a wider population, a transformation model has been proposed. MBA students and learning facilitators may find this useful when planning MBA programme participation or facilitation, so that students gain the greatest possible value from the undertaking.

*To whom all correspondence should be addressed.

\section{Introduction}

And why do young managers leave well-paying jobs to spend tens of thousands of dollars on a business school?

Pine and Gilmore (1999:163)

This exploratory study is a contribution to the debate on the perceived value of the Master in Business Administration (MBA) degree. Many studies have examined the financial costs and gains of investment into educational studies, including MBAs (Parry, 1996; Phillips, 1997; Cascio, 2000; Phillips, Stone \& Phillips, 2001; Van Niekerk \& Penman, 2002; Tunca, 2003; Furlonger, 2004), often linking their findings to a Return on Investment (ROI) or Rate of Return (ROR) model (Van Niekerk \& Penman, 2002; Connolly, 2003). Since the ROI concept deals in monetary units, both costs and returns are in the same format, and calculating ROI is a relatively simple matter of deducting the costs from the returns and calculating a percentage from the result (Phillips, 1997; Phillips et al., 2001), as follows:

ROI $=\frac{\text { Programme benefits }- \text { Programme costs }}{\text { Programme costs }} \times 100$
The ROR examines the percentage return from an investment, so is again purely financially based; such rates have also been investigated and published (Connolly, 2003).

However, it is suggested here that a more holistic picture of the value of an MBA, at least to graduates, should be considered by exploring perceptions rather than numbers, and aspects other than financial, which may contribute to the overall value that they obtain from engaging in MBA study. Thus, this study is by nature a pilot investigation on which further research may be based. References to 'ROI' in this report have been interpreted loosely so that graduate perceptions, which refer to different variables in the cost and benefit categories, may be weighed against one another, rather than deducted from one another as the financial ROI model would require.

Investigations into the value obtained from educational interventions have generally taken two forms; one focusing on the ROI of training interventions within and for the corporate environment (Parry, 1996; Phillips, 1997; Cascio, 2000; Fitz-Enz, 2000), others on the direct financial returns (be they ROI or ROR) to students undertaking higher education. References to these figures for MBA degrees are plentiful and available from universities offering the 
qualification; ROI calculators are provided on many websites (Braeger, 2002; Tunca, 2003).

In order to explore whether students perceive there to be costs and benefits other than financial, which may influence their perceptions of the worth of the qualification, the study design allowed free input to open ended questions in a first phase. The results of the initial survey were then combined with the literature review to formulate a more comprehensive questionnaire, which was applied to a larger sample $(n=54)$.

MBA students invest a great deal of time and make personal sacrifices for the sake of their higher education (Braeger, 2002). Of interest here is the articulation of the nature of the personal sacrifices (i.e. the costs) and the establishment of whether and how the overall benefits of the MBA make these sacrifices worthwhile (the return of a holistic array of benefits over the totality of financial and non-financial costs).

Implicit in students' perception of the value of an MBA is whether they learned what they needed to learn in order to become effective managers; published work in the area of competency models for managers is almost too plentiful (Boyatzis, Cowen \& Kolb, 1995; RSA, 1995; Meyer \& Semark, 1998). However, by focusing on the requirements of the skills development legislation (RSA, 1995; SAQA, 2003), it was possible to narrow down the array of possibilities to the core, generic outcomes (or metacompetencies) required in all registered qualifications; the critical cross-field outcomes or CCFOs. Although Mintzberg (2004) has launched an attack on MBAs, he does nonetheless list almost identical competencies as being key to effective management. Mintzberg's (2004) work also confirms the importance of different learning methodologies in adding value to the MBA experience in terms of competence development.

\section{Literature review and propositions}

It is agreed by many authors (Argyris, 1991; Spencer \& Spencer, 1993; Horwitz \& Bowmaker-Falconer, 1996; Phillips et al., 2001; Nordstrom \& Ridderstrale, 2002; Van der Sluis, 2002) that, in order to remain competitive, management knowledge and skills need to be constantly upgraded. The MBA was selected for this investigation because it is an authoritative credential worldwide in today's business environment (Bezuidenhoudt, 1997; AMBA, 2003; Tunca, 2003).

Meyer and Semark (1998) describe competence as the demonstration of integrated knowledge, skills, personal attributes and values. This definition is embedded in the noun 'competency', meaning a specific learning outcome. The concept has been applied in international qualifications frameworks (RSA, 1995; New Zealand, 2000; United Kingdom, 2000; United Kingdom. Department of Education and Employment, 2000a, 2000b; Scotland, 2003; Australia, 2003). This is the definition applied when referring to competencies in this paper. Identification and inclusion of required management competencies into MBA delivery will enhance the value of the qualification for leaders and managers (Bezuidenhoudt, 1997, Mintzberg, 2004).

Meyer (1996) identified clusters of generic competencies that he called meta-competencies. These fall broadly into the areas of communication, gathering and interpretation of data from a variety of sources, problem solving, systems thinking, ability to apply the use of technology in the workplace, working in groups, teams or communities, using mathematical concepts and managing oneself and one's own learning and development. These meta-competencies are 'essential skills that underpin success in education, employment, lifelong learning and personal development' (United Kingdom. Department of Education and Employment, 2000a:2). The CCFOs (Isaacs, 2000; RSA, 2000; SAQA, 2003) embedded within South African qualifications are similar; informing both the learning outcomes and assessment criteria specified within qualifications. This study is concerned only with the first seven CCFOs, as being those being assessable in students (Isaacs, 2000).

Current, financially-based ROI models (Kirkpatrick, 1979, 1996; Parry, 1996; Rothwell, 1996; Phillips, 1997; Van Greunen, 1998) incorporate the concept that competence must be addressed before performance can be expected (Kirkpatrick, 1979, 1987, 1996; Mager \& Pipe, 1997), which would then lead to business results. In South Africa, competence is described by the demonstration of learning outcomes in the following categories (RSA, 2000):

Foundational competence: The knowledge and understanding underpinning the practical aspects of what the learner is doing and why they are doing it.

Practical competence: The skill to perform a set of tasks in an authentic context.

Reflexive competence: The integration of performance with understanding, reflecting the learner's ability to adapt appropriately to changed circumstances

An additional aspect of learning has been included here that of 'worldview'. It is not a term that SAQA uses, but has come to replace the word 'attitude' in the business world. It is intended to reflect certain wisdom about the way the world operates, and may include attitudes, attributes and values. Mink (1992), cited in Collins (1996:14) describes worldview as 'a way of seeing, feeling and touching the world, in terms of perceiving, understanding and interpreting.'

\section{The adult learning process}

Haggis (Haggis 2002) suggests that the adult learning process is not a simple one, that there is no one best way for all individuals in all circumstances, and that theories of adult learning should not be seen as 'universal truths' to be simply applied for academic success. However, there does seem to be general agreement that adults learn best through experiential learning (Kolb, Rubin \& McIntyre, 1971; Honey \& Mumford, 1992; Brock \& Cameron, 1999; Margolis \& Swan, 1999; Desai, Damewood \& Jones, 2001) 
that is both active and collaborative (Frazier and Keller 1992). Adult learners need facilitated knowledge acquisition, conceptual understanding and a logical course structure (Westermann and others 2002), which may be enhanced by good relationships with staff (Rowley and Slack 1998); (Haggis 2002), especially when the teacher / learner interaction is informal (Dawson, 1994). By taking note of the factors that students identify as enhancing their learning experience, faculty would be able to apply them to facilitate deeper levels of understanding. This should, in turn, lead to more effective application of the newly acquired skills back in the workplace, enhancing the value of the course of study to graduates.

Isaacs (2001) describes assessment as being integral to learning, rather than only to establish the grade of the student. In South Africa, formative assessment is an activity that takes place during the course of learning, while summative assessment takes place at the end of a course, and includes the content of the entire course (SAQA, 2003).

\section{Learning methodologies for MBA students}

Learning methodologies have been classified in terms of a number of different models (Linstead, 1990; Dyrud, 1997). In order that student perceptions regarding the effectiveness of different learning methodologies could be explored, only those methodologies that applied at the institution, and had supporting literature, were investigated. These were: lecturing (both formal and interactive), computer-based instruction, case studies, formative assessments, video, individual and syndicate assignments, panel discussions, networking, conducting research, field trips, international visits, class presentations, guest speakers, simulations, action learning, and peer evaluation (Rothwell, 1996; Hitchcock, 1996; Doody, 1997; Malone, 1997; Evans \& Abbott, 1998; Margolis \& Swan, 1999; Cadman, 2000; Phipps, Phipps, Kask \& Higgins, 2001; Chonko, Tanner \& Davis, 2002; SAQA, 2003).

\section{HR ROI methodologies and models}

When investigating educational interventions, a brief review of the historical development of the concepts will assist in understanding how they have evolved into concerns about the value perceived by MBA students.

Measuring the return on human resource interventions has been notoriously difficult, and much has been written on the topic (Parry, 1996; Sveiby, 1989; Phillips, 1996, 1997; Bassi, Ludwig, McMurrer \& Van Buuren, 2000; Cascio, 2000; Fitz-Enz, 2000; Phillips et al., 2001), with several models for financial measurement being proposed. As Human Resources is being held more accountable for their contribution to business results (Ulrich, 1998), the idea that education and training should demonstrate a return on investment has become popular.

Kirkpatrick (1996) first defined and popularised the fourlevel hierarchy of evaluation that is used extensively and has been adapted in a number of the financial ROI models in use today (Kirkpatrick, 1979, 1996; Parry, 1996; Rothwell, 1996; Phillips, 1997). The original four levels have more recently been expanded to include the fifth level of ROI measurement (Phillips, 1997). Figure 1 illustrates.

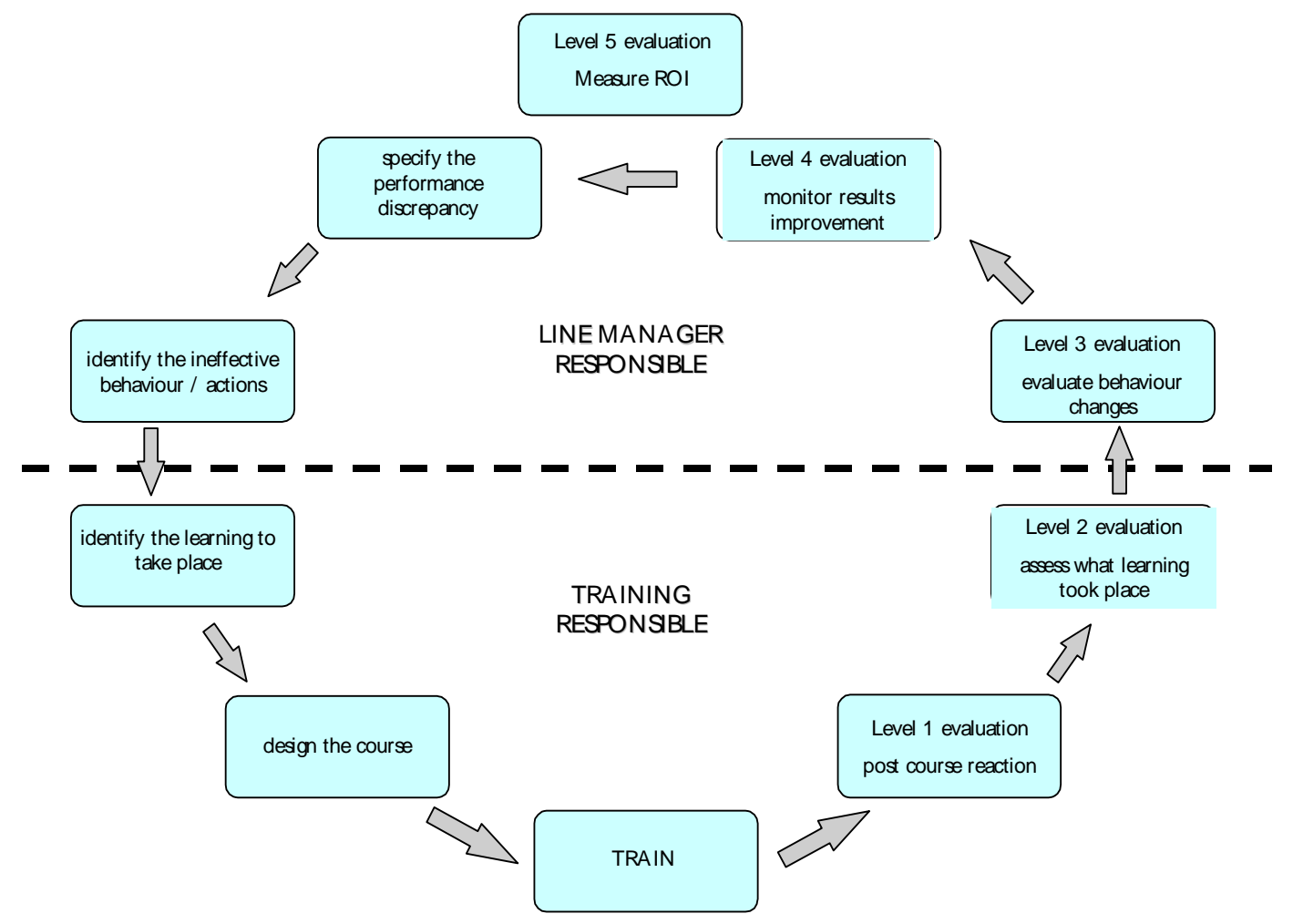

Figure 1: Donald Kirkpatrick's evaluation hierarchy with Phillips' fifth level inserted Sources: Kirkpatrick, 1979, 1996; Phillips 1996, 1997. 
Measurement at levels one (reaction) and two (learning) can easily be performed, and are the responsibility of the educators in the process (Kirkpatrick, 1996). However, the more meaningful levels three (behaviour change) and four (business results) require evaluation back in the workplace, and as such are the responsibility of line management, who may not have the necessary skills or motivation to do so. Another difficulty at the two higher levels is that there are other factors affecting workplace performance (Parry, 1996; Mager \& Pipe, 1997), which may have no relationship to the skills or competence of individuals.
Phillips (1997) includes evaluation at all levels as input into his model for measuring ROI (Figure 2), isolating the effects of training by including a control group. Although he quantifies where possible, he is left with a category of intangible benefits that cannot be expressed in terms of the monetary value of their accrued benefits. The existence of these intangibles supports the theory proposed here, that a more holistic framework of the value of a course of study can be constructed.

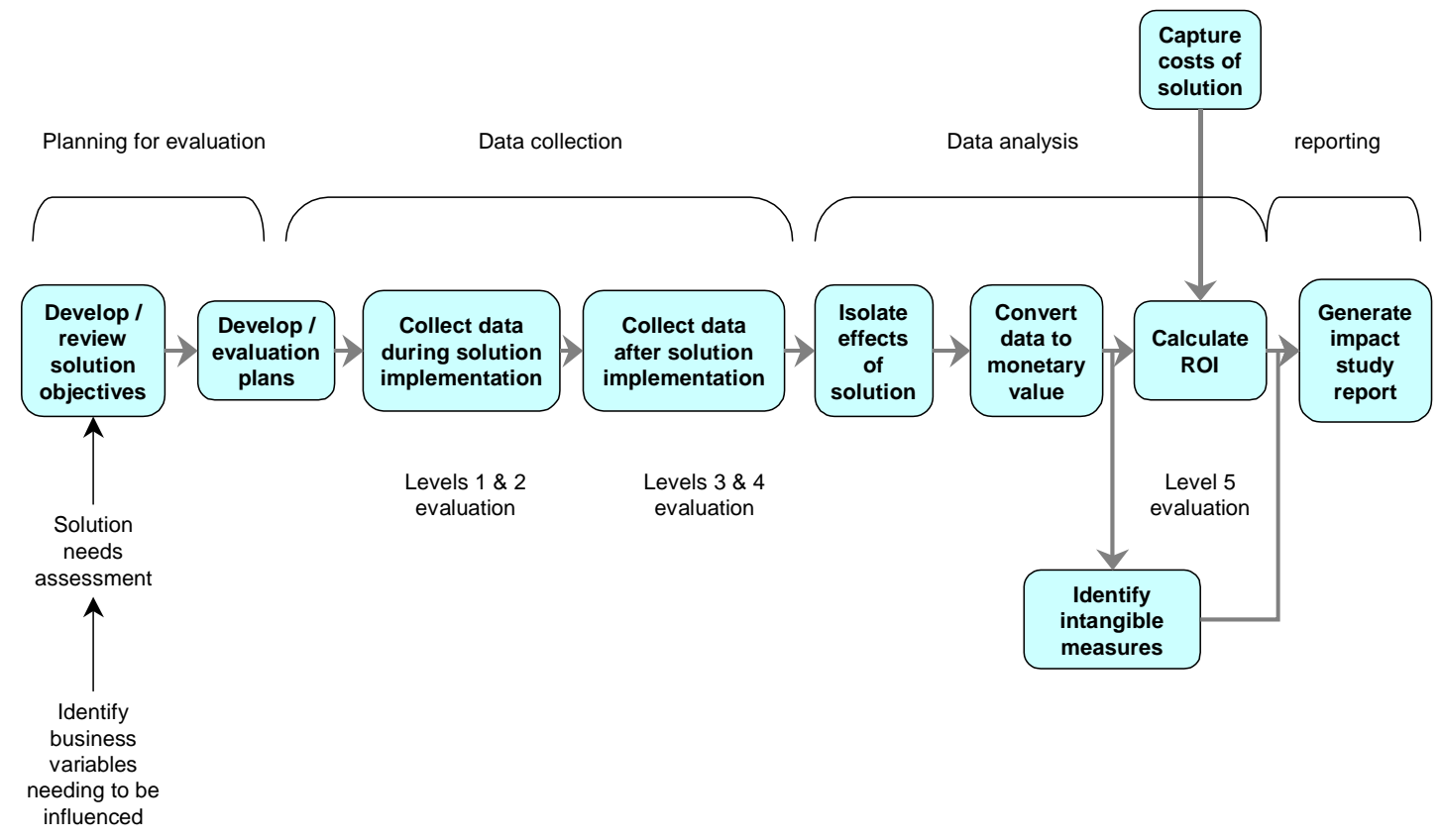

Figure 2: Phillips' model for the calculation of ROI for an HR intervention Source: Phillips, 1997.

Phillips' (1997) assumption underlying the inclusion of all levels in the ROI calculation is that the levels build on one another; learner satisfaction with the way the programme was run (level 1) is a precursor to learning (level 2), which is necessary for workplace behaviour to change (level 3) in order that business results may improve (level 4). He maintains that the 'chain of results' (Phillips, 1997:10) measured during the process adds validity to the theory that positive change is the result of learning and not some other factor. The financial ROI calculation of the intervention acknowledges that a cost / benefit figure or ratio is vital as a business measure of the intervention's contribution to the corporate bottom line. The objective of this description is to illustrate the point that Phillips (1997) makes a direct link between the students' learning experience and the corporate bottom line. This research extracts the variables affecting the students' experience (level one evaluation) and projects forward theoretically to the students' personal bottom line, as seen in the proposed holistic framework model in Figure 8.

\section{Categories of costs and benefits in an MBA}

Cost and benefit variables relating to the currently used ROI models are clearly financial in nature (Phillips, 1997; AMBA, 2003), although some work (Malone, 1997;
Cadman, 2000; Cascio, 2000; Phillips et al., 2001; Braeger 2002; AMBA, 2003; MBA.com, 2003) refers to 'other' variables, for example Phillips et al.'s (2001) 'intangibles'. It was clear from phase one of the study that students also considered variables such as time committed, personal relationship effects, establishment of networks and improved self-confidence to be valid constructs influencing their perceived value of the qualification.

\section{Research propositions}

The following propositions were formulated from gaps identified in the literature:

\section{Proposition 1:}

Student perceptions of the cost and benefit variables associated with an MBA degree go beyond those of only a directly financial nature.

\section{Proposition 2:}

SAQA's CCFOs are perceived by MBA graduates to be relevant management competencies, and are perceived to be developed through an MBA programme. 


\section{Proposition 3:}

Different learning methodologies applied during MBA programmes contribute to the students' overall experience and self-perceptions of competence.

\section{Research methodology}

The two-phased study was exploratory, qualitative and perception based (Miles \& Huberman, 1994; Carter, 1997; Leedy \& Ormrod, 2001; Robson, 2002); it was intended to contribute to the debate around the value of an MBA and provide a baseline for further research, rather than to attempt to generalise to other similar contexts.

Phase one was simply to obtain input and key phrases, so asked simple, open-ended questions about personal experiences and perceptions, and respondents were free to answer in their own words. The variables relating to the study were extracted by content analysis of these interviews. These data, with complementary published findings, were included in the survey questionnaire (phase two), which was piloted before use. No attempt was made to gather quantitative financial data.

\section{The research population and sample}

The population was defined to include all MBA students who graduated between the years 1998 and 2002 from Wits Business School. The period was selected based on the findings of Van Niekerk and Penman (2002), where almost all graduates had recouped their financial costs after five years. In addition, the sample needed to be of relatively recent graduates so that they would be able to recall their experiences more fully. Racial and gender quota sampling (Leedy \& Ormrod, 2001) was applied to the defined population on a convenience basis, resulting in 54 completed responses with a demographic profile that matched that of the average of the six most recent MBA classes. This was done to add population representivity to the study.

\section{Limitations and delimitations of the study}

The sample was highly biased due to the convenience basis of selection and the limited defined population, so the findings should be interpreted cautiously. Although stratified random sampling (Robson, 2002) would have yielded more generalisable data, lack of sources with the required stratified demographic information about the population rendered this approach problematic. For this reason non-probability based quota sampling was used (Leedy \& Ormrod, 2001; Robson, 2002), with the understanding that statistical inference and generalisation would not be possible. However, qualitative data can be transferable (Bendixen, 2002), and it is anticipated that the findings here will be useful to other MBA students.

\section{Research results and discussion}

The currently used financially based ROI models (Phillips, 1997; Fitz-Enz, 2000; Phillips et al., 2001) do not elaborate on the intervention itself (learning methodologies and competence development) as an integral part of the equation. This omission of the 'what' and 'how' of the learning process may not be significant in the calculation of the actual ROI, but the disaggregated detail within the process provides clues to a more holistic framework to describe the perceived value of educational interventions to students.

\section{Proposition 1:}

Student perceptions of the cost and benefit variables associated with an MBA degree go beyond those of only a directly financial nature.

A number of variables were identified by students as contributing to the value of their MBA experience. These are shown in Figure 3. The respondents had defined both costs and benefits into categories of 'financial' and 'nonfinancial', although they were not requested, by design, to quantify any of the variables in financial terms. However, the range of variables identified supports acceptance of Proposition 1.

The data obtained from the study were analysed by the categories identified by the respondents, viz. 'financial costs', 'non-financial costs', 'financial benefits' and 'nonfinancial benefits'. Figures 4 - 7 show the importance / frequency charts in which the constant-sum weighting (relative importance) of each variable was plotted against frequency of mention of the variable. The presentation of the findings in this way allowed an interpretation of the overall impact of the different variables to students.

Figure 4 ('financial cost' variables), shows that fees impacted on most students (high frequency) and was a large influence on that category (high weight). It follows, ceteris paribus, that lack of available funds to pay for tuition may be the greatest barrier to student entry. This is supported by the fact that most students pay either in whole or in part, for their own studies (Van Niekerk \& Penman, 2002). Text books were a cost factor for most students (high frequency), but had a relatively minor influence (low weight) on that category. All the variables identified in the four categories were interpreted in this manner.

To a prospective MBA student, financial costs (Figure 4) are the most pressing and immediate, for, without the funds, the student will not be in a position to register with the institution. A compounding effect to the perceived direct cost was that the second highest weighted cost in this category was that of financial opportunity cost, affecting nearly $60 \%$ of respondents. Those affected by both may anticipate experiencing an overwhelming financial loss in the short-term, which may negatively affect their decision to enrol. Although this study aims to advise students in the first instance, and learning experts / faculty in the second, it is suggested that there may be opportunities for business schools to support students with study funding. This could be either directly, through bursaries or scholarships, or indirectly by persuading corporations to offer similar bursaries or scholarships. 


\begin{tabular}{|c|c|c|}
\hline Benefits & $\begin{array}{l}\text { Category: Financial benefits } \\
\text { - Increased salary } \\
\text { - Leverage new career pathway } \\
\text { - Increased business contacts } \\
\text { - Improved job mobility } \\
\text { - Promotion } \\
\text { - Increase in other earnings } \\
\text { - Securing employment } \\
\text { - Increase in company benefits }\end{array}$ & $\begin{array}{l}\text { Category: Non-financial benefits } \\
\text { - Improved self confidence } \\
\text { - Broader worldview } \\
\text { - Greater knowledge } \\
\text { - Greater skills } \\
\text { - Control own destiny } \\
\text { - Greater job satisfaction } \\
\text { - Better quality of life } \\
\text { - Greater productivity } \\
\text { - Greater sense of values / ethics } \\
\text { - New close relationship } \\
\text { - Better relationship with friends / family }\end{array}$ \\
\hline Costs & $\begin{array}{l}\text { Category: Financial costs } \\
\text { - Tuition fees } \\
\text { - Financial opportunity cost } \\
\text { - International travel cost } \\
\text { - Text books } \\
\text { - Loss of company benefits } \\
\text { - Additional costs, eg stationery }\end{array}$ & $\begin{array}{l}\text { Category: Non-financial costs } \\
\text { - Reduced balance with other } \\
\text { areas of life } \\
\text { - High stress levels } \\
\text { - Deterioration of relationships } \\
\text { - Reduced contact with networks } \\
\text { - Non-financial opportunity cost } \\
\text { - Loss of self confidence }\end{array}$ \\
\hline & ingncial & Non-financ \\
\hline
\end{tabular}

Figure 3: Student perceptions of the cost and benefit variables associated with MBA study

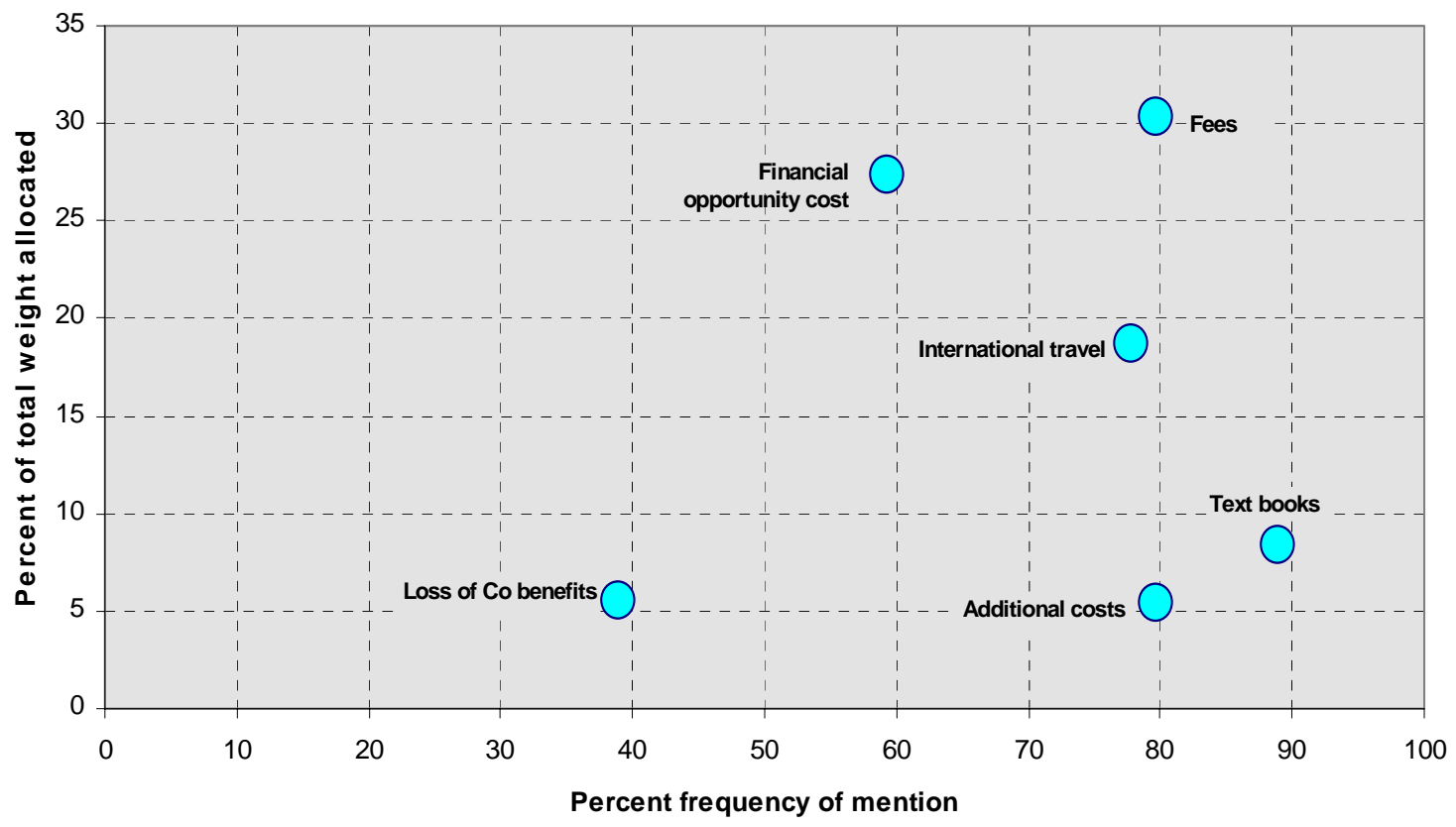

Figure 4: The perceived financial costs of an MBA 


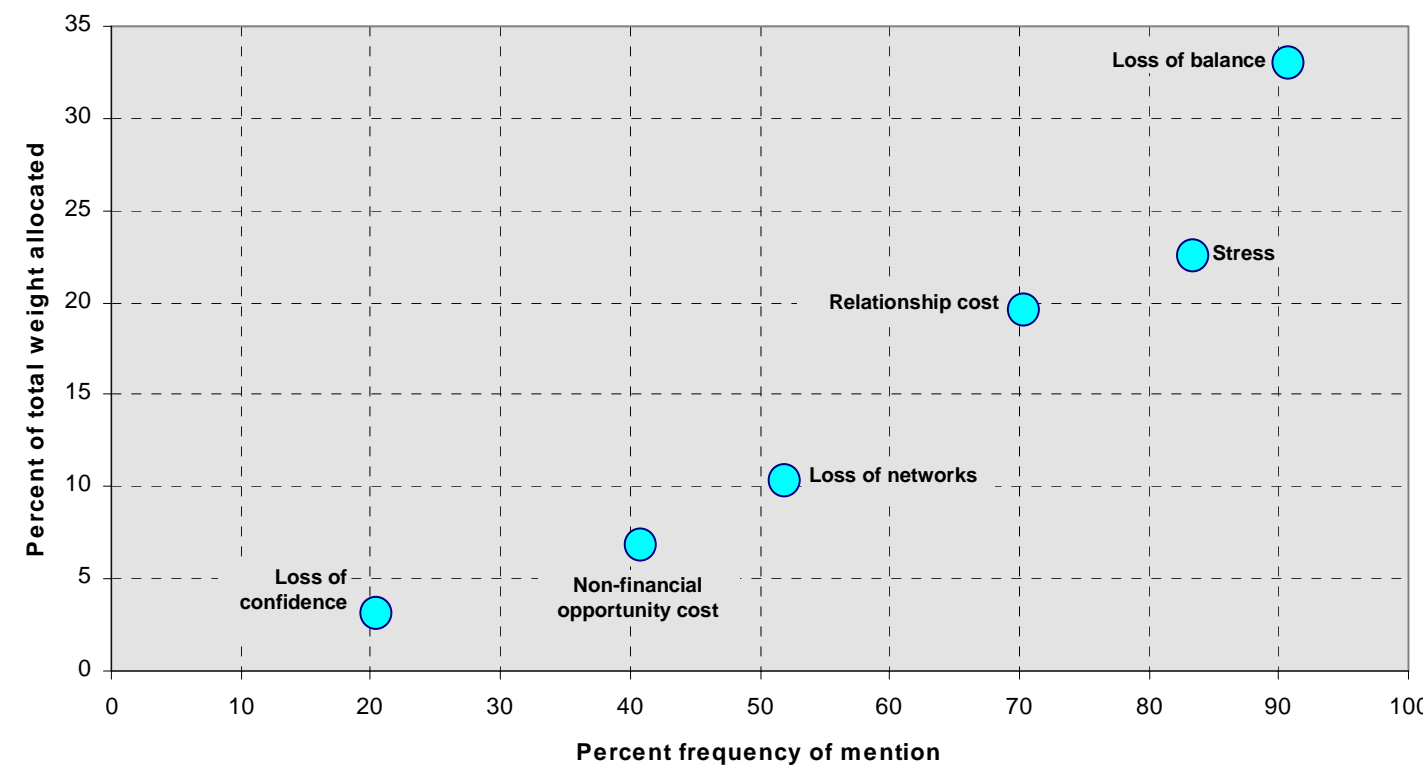

Figure 5: The perceived non-financial costs of an MBA

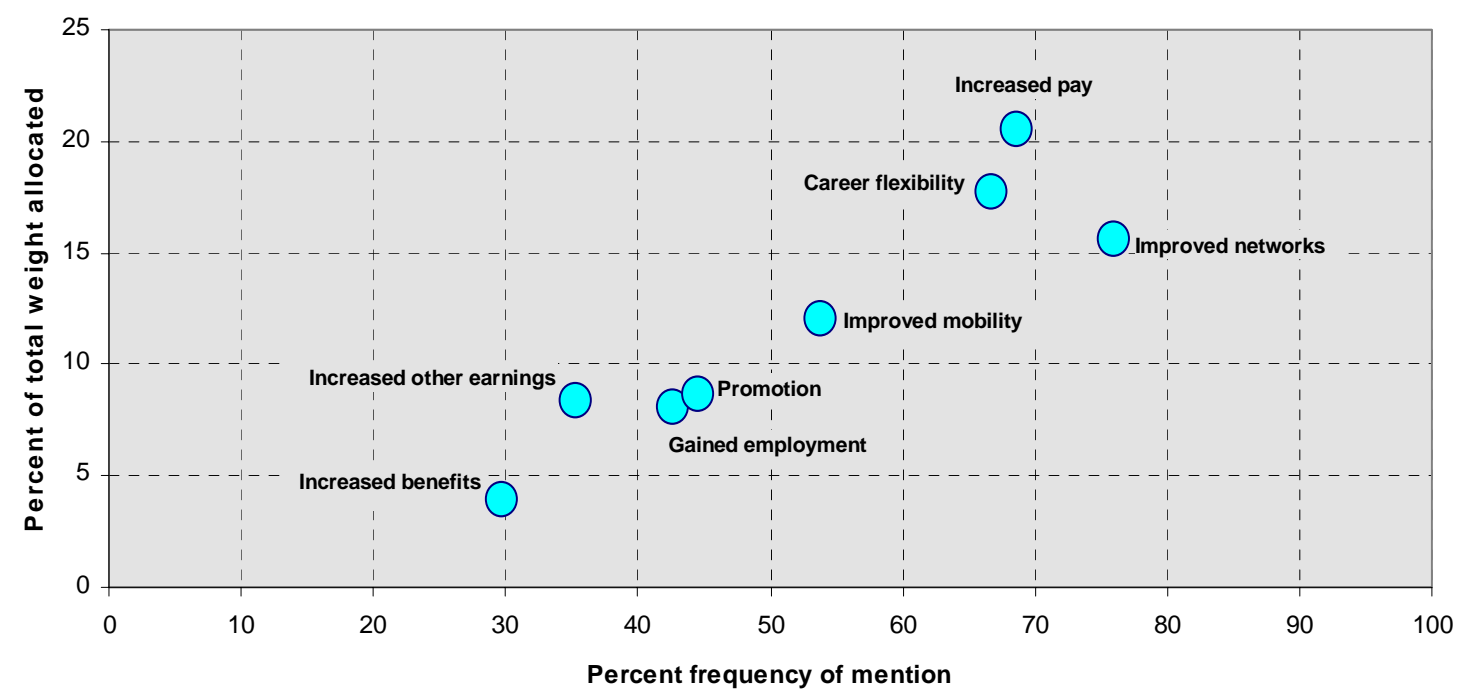

Figure 6: The perceived financial benefits of an MBA

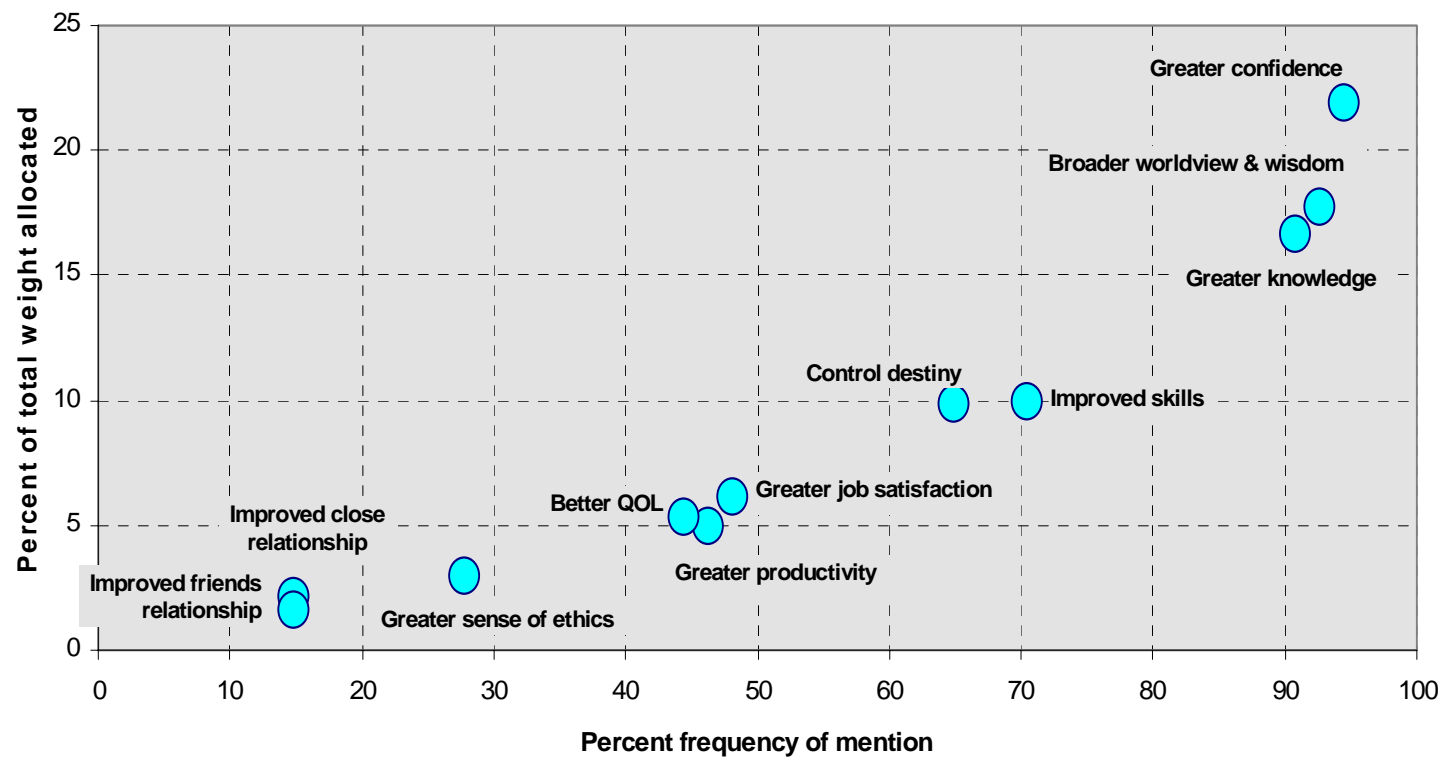

Figure 7: The perceived non-financial benefits of an MBA 
In Figure 5 ('non-financial cost' variables), loss of balance with other areas of life received the highest score for both importance (33\% of the weight allocation) and frequency, affecting some $90 \%$ of respondents. This was followed by stress, and then relationship cost, which was defined in terms of a deterioration of relationships with friends and family.

It will be noted in Figure 6 ('financial benefit' variables) that some of the items are directly financial, such as an increased salary, whereas others were perceived to fall into this category because they lead to financial benefits rather being financial benefits themselves.

Most (68\%), but not all, respondents were able to command higher salaries after completion of their MBA degree, and this variable received the highest weighting in this category, a reflection of its perceived importance. However, the highest response frequency $(75,9 \%)$ was with regard to the improved network of business contacts built up during the course of the study period. Just over $40 \%$ of respondents were promoted and a similar number were able to secure employment as a direct result of their studies. A third of the respondents (35\%) were able to improve their earnings from alternative sources, but this did not amount to anything of great significance (weight of $8,4 \%$ ).

In a traditional ROI study, it would not be possible to quantify many of these variables in financial terms, although they are clearly important to students. This is illustrated strongly in Figure 7 ('non-financial' benefit variables), where the widest range of variables was identified by the sample as contributing positively to the perceived value of their MBA.

The three most important (highest weighting) variables; a) increased confidence, b) broader worldview / insight / wisdom, and c) significantly greater knowledge, each scored greater than $90 \%$ frequency, and together, accounted for more than half of the total weight allocation. These 'nonfinancial' benefits may begin to develop during the course of the MBA as students make progress with their studies, but it is likely that the full impact will only be brought to bear once they return to a full work commitment and are able to compare themselves to their peers and colleagues who have not undertaken an MBA degree.

The lowest allocations in this category went to the improvement of relationships within the family (2,2\%), and within the social circle $(1,6 \%)$. MBA students should be particularly aware that, should their close relationship deteriorate because of their studies, this research suggests that they are unlikely to regain it after graduating.

In order to determine whether, in an overall, holistic sense, the perceived benefits of doing an MBA outweighed the perceived costs, the respondents were asked to state whether the overall benefits were greater than, equal to or less than the overall costs. The results were that $98,1 \%$ stated that the benefits were greater than the costs.

The extent and scope of the responses to the questions regarding a holistic view of the cost and benefit variables influencing students' perceptions of the value of their MBA show clearly that there is more to 'ROI' than simply financial measures, and that the overall benefits of doing an MBA are perceived to outweigh the overall costs by $98,1 \%$ of the sample.

\section{Proposition 2:}

SAQA's CCFOs are perceived by MBA graduates to be relevant management competencies, and are perceived to be developed through an MBA programme.

The reviewed literature strongly suggests that SAQA's critical outcomes are valid competencies for leaders and managers (New Zealand, 2000; United Kingdom, 2000; United Kingdom. Department of Education and Employment, 2000a; AMA, 2001; Australia, 2003), and have been described by leaders such as Guiliani (2002). In addition, Spencer and Spencer (1993) write that technical competence alone is only of value in predicting performance in technical tasks, but is a poor predictor of general performance in a business environment, which requires the development of human characteristics. These characteristics encompass most of the CCFOs and align well with those of Mintzberg (2004).

The respondents allocated a weighting factor based on a constant sum scale of 100 points between the generic management meta-competencies (SAQA's seven assessable CCFOs). These relate directly to student competence, so an option of 'other' was included to allow respondents to allocate points there if they felt that the seven listed factors were not sufficiently comprehensive.

The results of the weighting and perceived extent of improvement of these metacompetencies may be seen in Table 1. A mean weight of only 3,89 was allocated to 'other', indicating that all seven assessable critical crossfield outcomes were perceived to be relevant to MBA students. The data also show that all were improved to some extent during the programme; solving problems and critically evaluating information achieved the most improved scores, and use of technology the least.

There is an important difference between the Spencer and Spencer (1993) profile and that of the CCFOs, despite their use of similar terminology. The Spencer and Spencer (1993) definitions are descriptive, and not results (outcomes) focused, whereas the CCFOs provide general, but clear definitions of what individuals should know and be able to do to demonstrate competence. The similarities between the two profiles despite the ten-year interval between them suggest an enduring quality about these fundamental issues, which have recently been reconfirmed (Mintzberg, 2004).

Randall's (1993) concerns about education in South Africa being insufficiently transformational would be allayed if these core competencies were to be deliberately developed in all educational endeavours. MBA students and graduates should take it upon themselves to interact co-operatively with the world and others around them, to improve their productivity and develop a pragmatic, problem-solving outlook. These endeavours can be supported by facilitators 
of learning through teaching methodologies and curriculum development.

Based on the findings described, Proposition 2 may be accepted.

\section{Proposition 3:}

Different learning methodologies applied during MBA programmes contribute to the students' overall experience and self-perceptions of competence.

The respondents were asked to rate the effectiveness of learning methodologies identified as having been applied during their MBA, and to state the one methodology that they had found to be the most effective of all. On this basis, the methodologies perceived to be the most effective were: interactive lectures and discussions in class, syndicate assignments, individual assignments, case studies in class, guest speakers, and doing own presentations to class. The least favoured were formal (non-interactive) lectures, videos shown in class, simulations and the examination process. A number of students did qualify their selections by stating that their choice was dependent on the particular lecturer.

The findings from this study align with existing knowledge about the preferences of adult learners; in that learning should be experiential, collaborative and facilitated, to be most effective, as follows: a. Experiential learning activities (Kolb et al., 1971; Linstead, 1990; Honey \& Mumford, 1992; Dawson, 1994; Brock \& Cameron, 1999; Margolis \& Swan, 1999; Desai et al., 2001) such as assignments, case studies, international exposure, the research process, simulations, field trips and presentations to class totalled $83 \%$ of all responses for 'best methodology'.

b. Group or collaborative learning (Frazier and Keller 1992) is preferred by adults. Respondents in this study favoured the opportunities to learn from interactive lectures, syndicate assignments, case studies in class, networking with class members and simulations, which together accounted for $64 \%$ of the responses.

c. The perceived usefulness of classroom learning in the form of interactive lectures and case studies found here combines the two main preferences of adult learning described above into experiential, collaborative learning. Adults have been found to learn better when knowledge acquisition and conceptual understanding is facilitated (Westermann and others 2002).

Proposition three may also be accepted on the basis of the findings.

Table 1: Perceived importance and extent of improvement of SAQA's assessable critical cross-field outcomes by MBA graduates

\begin{tabular}{l|c|c}
\hline Generic management meta-competency (CCFO) & Mean weight (Total = 100) & \%age improvement \\
\hline Identifying and solving problems using critical and creative thinking skills & 17,81 & $98,1 \%$ \\
\hline Collecting, analysing, organising and critically evaluating information & 16,33 & $98,1 \%$ \\
\hline Working effectively with others as a member of a team or group & 15,91 & $92,6 \%$ \\
\hline Communicating effectively, verbally and in writing & 13,93 & $90,7 \%$ \\
\hline Ability to see the world as a set of interrelated systems & 13,50 & $85,2 \%$ \\
\hline Organizing and managing oneself responsibly and effectively & 11,35 & $74,1 \%$ \\
\hline Using technology effectively & 7,28 & $35,2 \%$ \\
\hline Other & 3,89 & 0 \\
\hline
\end{tabular}

\section{A holistic framework for the perceived return on investment in an MBA}

Through analysis and discussion of the findings of this study, it has been possible to construct a holistic framework of the MBA process. The transformation based model (Figure 8) can be applied by students in order to obtain maximum benefit from their MBA experience by managing the inputs (cost variables), taking maximum advantage of the elements making up learning process, and taking accountability for implementation of their learning back at the workplace, so that they perform optimally and thereby reap the benefits in a holistic way. Faculty and experts on learning may also find the model useful in seeking ways to positively influence students' perceptions of the ROI they obtain from their studies, in a more holistic sense.

In this study, students have been considered as stakeholders rather than customers of the institution (McNary, 1994; McCullough \& Gremler, 1999). Institutions aim to provide students with an education as well as a degree certificate, so need to provide an experience that takes both process and outcome into account.

The perspective is that of the student-as-stakeholder. In this model, students are putting themselves through a transformation process in order to be educated. They have certain cost inputs to this process, some of which may be 
measured financially. Others that are less definable, but nonetheless important, include time pressure, stress, and relationship deterioration. Their objective in undertaking the course of study is linked to the benefits that they anticipate receiving as a result of their efforts, shown as stakeholder outcomes in the model.

By articulating objectives for their MBA, students would be able to focus on the benefits to be received by undertaking an MBA rather than the costs, which apply mainly at the beginning of the course. This may motivate them to participate more actively in the programme and take a greater level of accountability for their own learning. The difficulty in maintaining focus is that both the financial (Figure 6) and non-financial benefit variables (Figure 7) are not only uncertain in scope and extent, but in the distant future. It is only the graduated MBA student who is in a position to objectively assess the overall worth of taking the course, and then only a year or more after completion (Van Niekerk \& Penman, 2002).

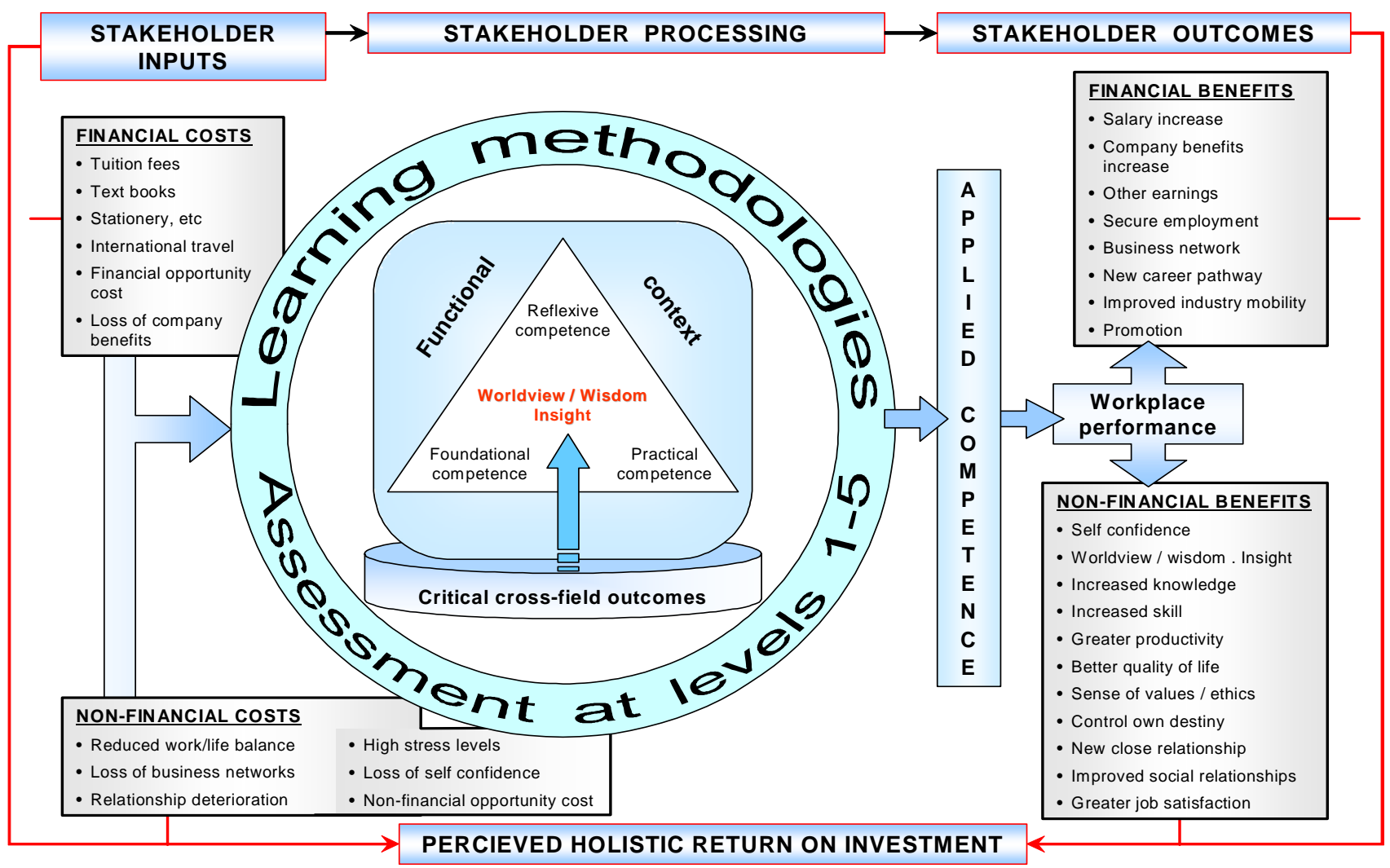

Figure 8: A holistic framework for the perceived return on investment in an MBA

The circle represents the role and activities of faculty and learning facilitators in 'processing' the student. This processing activity includes the learning methodologies applied during the course, with the aim of developing the applied competence of the student through contextually relevant knowledge and skills acquisition (foundational and practical competence), underpinned by the development of a broader worldview, insight and wisdom. By extending assessment into the workplace (i.e. implementing all five of Phillips' (1997) levels), the graduate can build themselves to a higher level of applied competence, leading to workplace performance and ultimately financial and non-financial benefits. The enhanced benefits are unlikely to materialise without improved performance, and it is suggested that MBA graduates be particularly aware that competence is not the same as performance, but that competence leads to performance. The degree certificate is not sufficient on its own to bring enhanced benefits; there is much work to be done once this has been achieved.

\section{Recommendations}

By considering students as key stakeholders rather than customers, learning facilitators may meet both their own objectives as well as those of MBA graduates. Students do need to take responsibility for their own learning within the institutional environment, and work constructively with faculty to maximise their ROI from a holistic perspective.

\section{Recommendations for current and prospective MBA students}

Students can apply the model (Figure 8) developed in this study to create a plan for their MBA study. Firstly, they need to commit themselves to completing their degree and graduating. Prospective MBA students may plan their study period in realistic terms by evaluating the potential or anticipated impact of each cost variable (Figures 4 and 5) to themselves, and negotiating support from business contacts, 
friends and family, including their partner, for the duration of the MBA, as relationships with these groups of people may suffer as a result of the imbalance and stress (Figure 5) that accompanies MBA study.

Students can maximise the holistic ROI of their MBA by constructively and actively participating in learning activities, including preparation, class discussions and assignments in order to enhance their learning, remembering that these first commitments lead to behaviour change back in the workplace, followed by improved business results.

Students are encouraged to collaborate with their facilitators regarding their use of effective learning methodologies. They can work together with faculty so that each supports the other in the quest for both a rewarding and motivating learning experience and a higher graduation rate. In addition, students should encourage their class peers to share their expertise so that they may build their own, based on collaborative efforts and teamwork.

Once MBA students have graduated and are back in the workplace, they are out of the scope of influence of the educational institution and its faculty. This requires that they take full responsibility for levels three and four evaluations of their learning (Kirkpatrick, 1979, 1987, 1996; Phillips, 1996, 1997), and self-monitor to ensure implementation of their learning and the anticipated business results and personal rewards that follow. Phillips (1997) recommends that level one evaluation is carried out immediately postcourse, level two at the end of the programme, level three a few weeks after the programme and level four a few months after the programme.

\section{Recommendations for faculty and learning facilitators}

Learning facilitators should view students as key stakeholders of the business, with both obligations and expectations of the relationship. They should be aware of and empathetic to the cost and benefit variables that are important to students, and support them to experience the holistic range of benefits that they may enjoy.

Faculty can enhance the effectiveness of learning interventions by using the methodologies that students find most effective and encouraging participation in learning activities. In addition, all learning and teaching experts need to recognise the importance of the critical cross-field outcomes in leader and manager development and take steps to articulate them clearly and build an appreciation of them into the MBA course.

\section{Conclusion}

This research has identified that there are a number of variables, not necessarily financial in nature, which contribute to MBA students' holistic perception of the value of their qualification. A framework based on a transformation model has been proposed, so that students and faculty may take advantage of a greater number of factors in order to attain a more holistic and positive perception of the MBA experience.
The company's economic offering is neither the materials it uses nor the physical things it makes. It is neither the processes it executes, nor the encounters it orchestrates. When a company guides transformations, the offering is the individual . . . the expectations centre on the customer [stakeholder] himself, on what he wants to become.

(Pine \& Gilmour, 1999:173)

\section{References}

Argyris, C. 1991. 'Teaching smart people how to learn', Harvard Business Review, 69(3):99-110.

AMA (American Management Association). 2001. 'American Management Association survey: Managerial skills and competence', [online] URL:

www.amanet.org/research/archives.htm. Accessed 9 April 2003.

AMBA (Association of MBAs). 2003. 'How I benefit from an MBA', [online] URL: www.mba.org.uk. Accessed 9 April 2003.

Australia. Australian Qualifications Framework (AQF). 2003. 'National Training Information Service', [online] URL: http://www.ntis.gov.au/cgi-

bin/waxhtml/ ntis/std.wxh?page=1. Accessed 9 April 2003.

Bassi, L.J., Ludwig, J., McMurrer, D.P. \& Van Buuren, M. 2000. Profiting from learning: Do firms' investments in education and training pay off? Alexandria: American Society for Training and Development. An ASTD Research White Paper

Bendixen, M. 2002. Academic style guide: Handbook for the preparation of research reports, project reports, research proposals, research papers, theses and dissertations. Johannesburg: University of the Witwatersrand.

Bezuidenhoudt, P.U. 1997. 'The role of MBA programmes within management education.' Unpublished MBA Research Report. Johannesburg: University of the Witwatersrand.

Boyatzis, R.E., Cowen, S.S. \& Kolb, D.A. 1995. Innovation in professional education: Steps on a journey from teaching to learning, San Francisco: Jossey-Bass.

Braeger, J. 2002. 'Opportunity cost for individuals', [online] URL:

www.why4u.com/UOP\%20PAPERS\%20Resume/ECON/O pportunity\%20cost\%20-MBA.doc. Accessed 19 ${ }^{\mathrm{h}}$ July 2003.

Brock, K.L. \& Cameron, B.J. 1999. 'Enlivening political science courses with Kolb's learning preference model', PS: Political Science and Politics, 32(2):25-27.

Cadman, K. 2000. “"Voices in the air”: Evaluations of the learning experiences of international postgraduates and their supervisors,' Teaching in Higher Education, 5(4):475-493. 
Carter, M.S. 1997. 'Psychological / Sociological Paradigms', [online] URL:

http://webpages marshall.edu/ carter12/eda705a5 htm.

Accessed 30 May 2003.

Cascio, W. 2000. Costing human resources: The financial impact of behaviour in organizations. 4th Edition. Cincinnati: South-Western College Publishing.

Chonko, L., Tanner, J., \& Davis, R. 2002. 'What are they thinking? Students' expectations and self-assessments', Journal of Education for Business, 77(5):271-281.

Collins, D. 1996. 'New paradigms for change? Theories of organization and the organization of theories', Journal of Organizational Change, 9(4):9-23.

Connolly, M. 2003. 'The end of the MBA as we know it?', Academy of Management Learning and Education, 2(4):365-367

Dawson, F. 1994. 'Good practice for postgraduate training: The postgraduate response', Journal of Geography in Higher Education, 18(3):370-373.

Desai, S., Damewood, E. \& Jones, E. 2001. 'Be a good teacher and be seen as a good teacher', Journal of Marketing Education, 23(2):136-145.

Doody, D.J. 1997. 'An evaluation of the Wits MBA programme in satisfying graduates' educational requirements and expectations.' Unpublished MBA Research Report. Johannesburg: University of the Witwatersrand.

Dyrud, M.A. 1997. 'Focus on teaching', Business Communication Quarterly, 60(2):124-135.

Evans, L. \& Abbott, I. 1998. Teaching and learning in higher education. London: Cassell.

Fitz-enz, J. 2000. The ROI of human capital: Measuring the economic value of employee performance. New York: Amacom, pp.129-159.

Frazier, P. \& Keller, R. 1992. 'Students and faculty administrators together', College Teaching, 40(1):21-24.

Furlonger, D. 2004. 'A winner for now', Financial Mail, 177(12):22-38.

Guiliani, R.W. 2002. Leadership. St Ives: Little Brown Books.

Haggis, T. 2002. 'Exploring the "Black Box" of process: A comparison of theoretical notions of the "adult learner" with accounts of post-graduate learning experience', Studies in Higher Education, 27(2):207-220.

Hitchcock, D. 1996. 'Learning from chaos: Why management training doesn't stick ...', Journal for Quality and Participation, 19(1):42-46.
Honey, P. \& Mumford, A. 1992. The manual of learning styles. $3^{\text {rd }}$ Edition. Maidenhead: Peter Honey.

Horwitz, F. M. \& Bowmaker-Falconer, A. 1996. 'Human resource development and managing diversity in South Africa,' International Journal of Manpower, 17(4/5):134152.

Isaacs, G. 2001. Teaching and learning in higher education series: The role of assessment in learning. Brisbane: University of Queensland.

Isaacs, S.B.A. 2000. The National Qualifications Framework and standards setting. Pretoria: SAQA.

Kirkpatrick, D.L. 1979. 'Techniques for evaluating training programmes', Training and Development Journal, 33(6):7892.

Kirkpatrick, D.L. 1987. 'Evaluation'. In Craig, R.L. (Ed.). Training and development handbook. $3^{\text {rd }}$ Edition. Alexandria: American Society of Training and Development, pp.301-319.

Kirkpatrick, D.L. 1996. Great ideas revisited', Training and Development Journal, 50(1):54-59.

Kolb, D.A., Rubin, I.M. \& McIntyre, J.M. 1971. Organizational psychology: An experiential approach to organizational behaviour. 4th Edition. New Jersey: Prentice Hall.

Kuh, G.D. 2003. 'What we're learning about student engagement from NSSE', Change, 35(2):24-33.

Leedy, P. \& Ormrod, J. 2001. Practical research: Planning and design. New Jersey: Prentice-Hall.

Linstead, S. 1990. 'Developing management metacompetence: Can distance learning help?' Journal of European Industrial Training, 14(6):17-27.

Mager, R. F. \& Pipe, P. 1997. Analyzing performance problems. $3^{\text {rd }}$ Edition. Atlanta: Centre for Effective Performance, Inc.

Malone, S.A. 1997. How to set up and manage a corporate learning centre. Aldershot: Gower Publishing.

Margolis, F. \& Swan, B. 1999. A trainer's handbook for participative learning. Massachusetts: HRD Press.

MBA.com. 2003. 'Evaluate the investment', [online] URL: www.mba.com. Accessed 9 April 2003.

McCollough, M. \& Gremler, D. 1999. 'Guaranteeing student satisfaction: An exercise in treating students as customers', Journal of Marketing Education, 21(2):119-122.

McNary, L. 1994. 'TQ in academe: Lessons from big business', Clearing House, 68(2):119-122. 
Meyer, T. \& Semark, P. 1998. 'A framework for the use of competencies for achieving competitive advantage', South African Journal of Business Management, 27(4):96-103.

Meyer, T. 1996. Creating competitiveness through competencies: Currency for the $21^{\text {st }}$ century. Johannesburg: Knowledge Resources.

Miles, M.B. \& Huberman, A.M. 1994. Qualitative data analysis: An expanded sourcebook. $2^{\text {nd }}$ Edition. Thousand Oaks: Sage Publications.

Mink, O.G. 1992. 'Creating new organizational paradigms for change', International Journal of Quality and Reliability Management, 9(3):21-35. Cited in Collins, D. 1996. 'New paradigms for change? Theories of organization and the organization of theories', Journal of Organizational Change, 9(4):9-23.

Mintzberg, H. 2004. Managers not MBAs. San Francisco: Berrett-Koehler Publishers, 260.

New Zealand. 2000. New Zealand Qualifications Authority (NZQA), [online] URL: http://www.nzqa.govt.nz. Accessed 10 April 2003.

Nordstrom, K. \& Ridderstrale, J. 2002. Funky business: Talent makes capital dance. Stockholm: Bookhouse Publishing.

Parry, S.B. 1996. Measuring training's ROI. Princeton: Training House Inc.

Phillips, J.J. 1996. ROI: 'The search for best practices', Training and Development, 50(2):42-47.

Phillips, J.J. 1997. Return on investment in training and performance improvement systems. Houston: Gulf Publishing Company.

Phillips, J.J., Stone, R.D. \& Phillips, P.P. 2001. The human resources scorecard: Measuring the return on investment. Woburn: Butterworth-Heinemann.

Phipps, M., Phipps, C., Kask, S. \& Higgins, S. 2001. 'University students' perceptions of co-operative learning: Implications for administrators and instructors,' The Journal of Experimental Education, 24(1):14-21.

Pine, B.J. \& Gilmore, J.H. 1999. The experience economy: Work is theatre \& every business a stage. Boston: Harvard Business School Press.

Randall, S. 1993. 'People's education and "Nation Building” for a New South Africa', Review of African Political Economy, 20(58):43-61.

RSA (Republic of South Africa). 1995. 'The South African Qualifications Authority Act No 58', Government Gazette No 152. Pretoria: Government Printer.
RSA (Republic of South Africa). 2000. 'Norms and standards for educators’, Government Gazette No 20844. Pretoria: Government Printer.

Robson, C. 2002. Real world research. $2^{\text {nd }}$ Edition. Oxford: Blackwell Publishing.

Rothwell, W.J. 1996. Beyond training and development: State-of the-art strategies for enhancing human performance. New York: Amacom.

Rowley, J. \& Slack, F. 1998. 'The first post-graduate experience conference', Journal of Further and Higher Education, 22(3):253-265.

Scotland. Scottish Qualifications Authority (SQA). 2003. Catalogue of National Qualifications Session 2003/2004. SQA Publication BA 0788. Glasgow: SQA Publisher.

SAQA (South African Qualifications Authority). 2003. Guidelines for the Assessment of NQF registered Unit Standards \& Qualifications. Pretoria: SAQA.

Spencer, L.M. (Jr) \& Spencer, S.M. 1993. Competence at work: Models for superior performance. New York: John Wiley \& Sons, Inc.

Sveiby, K.E. 1989. The invisible balance sheet: Key indicators for accounting, control and valuation of knowhow companies. Stockholm: Ledarskap.

Tunca, A. 2003. 'The value of today's MBA Degree', MBAA Journal, February. [online] URL: http://www mbaassociation.org. Accessed 9 April 2003.

Ulrich, D. 1998. 'A new mandate for human resources', Harvard Business Review, 76(1):124-135.

United Kingdom. Department of Education and Employment. 2000a. Guidance in using the key skills units. Qualifications and Curriculum Authority Publications QCA99/48. Sudbury: QCA Publications.

United Kingdom. Department for Education and Employment. 2000b. 'Key skills explained', [online] URL: http://www.dfee.gov.uk/progfile/index htm. Accessed 10 April 2003.

United Kingdom. Department for Education and Employment. 2000c. 'The National Vocational Qualifications', [online] URL: http://www.dfee.gov.uk/nvg/. Accessed 10 April 2003.

Van der Sluis, L. 2002. 'Learning behaviour and learning opportunities as career stimuli', Journal of Workplace Learning, 14(1):19-29.

Van Greunen, J. 1998. 'Return on investment in training. Unpublished training material. Johannesburg: Van Greunen \& Associates.

Van Niekerk, G. \& Penman, N. 2002. Financial Mail Project MBA, Johannesburg: Markinor. 
Westermann, R., Spies, K., Heise, E. \& Wollburg-Claar, S.

2002. 'Student evaluation of instruction and study conditions', European Education, 34(1):44-69. 